\section{An Evaluation of U.S. Peach Producers' Trait Prioritization: Evidence from Audience Surveys}

\author{
Chengyan Yue ${ }^{1,7}$ \\ Department of Horticultural Science and Department of Applied Economics, \\ University of Minnesota, Twin Cities, 1970 Folwell Avenue, St. Paul, MN 55108 \\ R. Karina Gallardo ${ }^{2}$ \\ School of Economic Sciences, Puyallup Research and Extension Center, \\ Center for Precision Agriculture and Automated Systems, Washington State \\ University, 2606 W. Pioneer, Puyallup, WA 98371
}

James J. Luby ${ }^{3}$ and Alicia L. Rihn ${ }^{4}$

Department of Horticultural Science, University of Minnesota, Twin Cities, 1970 Folwell Avenue, St. Paul, MN 55108

James R. McFerson ${ }^{5}$

Washington Tree Fruit Research Commission, 1719 Springwater Avenue, Wenatchee, WA 98801

Vicki McCracken ${ }^{6}$

School of Economic Sciences, Washington State University, P.O. Box 646210, Hulbert Hall 101, Pullman, WA 99164

Tom Gradziel ${ }^{3}$

Department of Pomology, University of California, Davis, CA 95616-8683

Ksenija Gasic ${ }^{3}$ and Gregory L. Reighard ${ }^{3}$

SAFES, Clemson University, Clemson, SC 29634

John Clark ${ }^{3}$

Department of Horticulture, University of Arkansas, Fayetteville, AR 72701

Amy Iezzoni ${ }^{3}$

Department of Horticulture, Michigan State University, East Lansing, MI 48824-1325

Additional index words. firmness, flavor, fresh peach, fruit size, processed peach, Prunus persica Batsch, split pit

\begin{abstract}
We conducted audience surveys at three major peach producer meetings across the United States. We found that the relative importance assigned to fruit quality and tree traits by producers varied across producers' end markets. Fresh peach producers indicated fruit flavor and size were the most important fruit quality traits, whereas processed peach producers viewed fruit size, fruit firmness, and absence of split pits as being the most important traits for a successful peach cultivar. These results have potential to ensure that peach breeding programs are consonant with fresh and processed peach producers' needs for fruit and tree traits.
\end{abstract}

Peach [Prunus persica (L.) Batsch] production is economically important throughout much of the United States. Globally, the United

Received for publication 22 May 2014. Accepted for publication 7 Aug. 2014.

${ }^{1}$ Associate Professor and Bachman Endowed Chair in Horticultural Marketing.

${ }^{2}$ Assistant Professor and Extension Specialist.

${ }^{3}$ Professor.

${ }^{4} \mathrm{PhD}$ Student.

${ }^{5}$ Manager.

${ }^{6}$ Professor and Associate Director.

${ }^{7}$ To whom reprint requests should be addressed; e-mail yuechy@umn.edu. fresh, $3.0 \mathrm{lbs}$ canned, and $0.7 \mathrm{lbs}$ frozen (ERS USDA, 2013).

Producers are challenged by increasing input costs to control invasive pests and diseases, meet regulatory demands, and especially for labor. Market intermediaries must deal with erratic supply, inconsistent quality, and fruit handling problems (Brunke and Chang, 2012). Consumers of fresh peaches are often frustrated with inconsistent flavor and textural quality, flesh browning, and insipid taste (Brunke and Chang, 2012). To enhance the efficiency of peach breeding programs developing scion cultivars to address the aforementioned supply chain challenges, a USDA-funded project called RosBREED has focused on enabling the use of marker-assisted breeding (MAB) in peaches and other rosaceous crops (Dirlewanger et al., 2004; Evans et al., 2012; Iezzoni et al., 2010). Implementing $\mathrm{MAB}$ requires substantial genetic knowledge, trained personnel, and financial resources, which underscore the importance of applying MAB to traits with the most favorable cost:benefit ratio across the supply chain for various rosaceous crops (Alpuerto et al., 2009; Luby and Shaw, 2001). This socioeconomic aspect was a fundamental component of RosBREED and this study of fresh and processed peaches sought to identify the most important traits for peach producers. This information will serve to compare priorities and needs from producers, market intermediaries (e.g., shippers, packers, and marketers), and consumers. It will also help identify the overall most important peach quality traits for MAB.

Selection of a scion cultivar in high-value specialty crops, especially perennials, is a crucial decision as a result of the high capital requirements for establishment and the delayed returns until a planting reaches full production. A producer must carefully consider the traits of a cultivar related to productivity and market acceptance. Ideally, a new peach orchard uses a scion cultivar with relatively high productivity and desirable characteristics through the supply chain (Florkowski et al., 2003; Jordan et al., 1986; Park and Florkowski, 2003). Important traits like freedom from defects, skin color, sugar level, and fruit size determine fresh peach prices (Jordan et al., 1986; Parker et al., 1991). Other traits like taste, texture, and pit characteristics also contribute to grower adoption of a cultivar (Park and Florkowski, 2003). The absence of decay and bruising are external traits important to producers and retailers (Park and Florkowski, 2003). However, the importance of different quality traits to supply chain members varies depending on the market channel for their products (Florkowski et al., 2003). For instance, if a producer is selling to a commercial packer, the packer values external traits because the peach will be resold making aesthetic traits important. In contrast, a retail consumer values taste making internal traits more important (Florkowski et al., 2003). Often, late-maturing peaches are selected by producers selling directly to retail outlets 
because late harvest maturity extends the harvest season, which can increase profits by filling a low-volume market window (Florkowski et al., 2003). Producers' decisions regarding the importance of peach fruit and tree traits are complex, making the quantification of the importance of these traits challenging.

Although this article focuses on peach producers' preferences for fruit quality traits for a successful new cultivar, traits important to consumers ultimately drive demand. In addition, most literature on preferences for peach quality traits is focused on consumers. Bruhn (1995) and Wolf et al. (2003) concluded that key peach traits were sweetness, attractiveness, firmness, ripeness, color, and aroma. Similarly, Predieri et al. (2005) showed that acidity, astringency, and sweetness resulted in greater consumer appreciation of a peach cultivar. Crisosto et al. (2003) found that soluble solids concentration and titratable acidity in ripe fruit impact consumers' preferences for cultivars, although the extent varies by cultivar. Overall, past studies demonstrate that peach quality traits impact consumers' preferences.

The objective of this study is to assess the importance of peach fruit quality and tree traits to U.S. fresh and processed peach producers. This information has potential to assist breeders and supply chain groups in determining key fruit and tree traits to target when breeding, producing, and commercializing new peach cultivars. In addition we assess whether producers' perceptions of fruit quality traits are consonant with consumers' preferences.

\section{Materials and Methods}

Pre-survey producer interviews. Before conducting the formal audience surveys, we interviewed five peach producers from different locations. The five peach producers were suggested by the advisory panel members of the project. The purpose of the pre-survey interviews was to develop the list of the traits for the audience survey. Producers were asked how they made decisions about what cultivars to grow, what were the major use/market of their fruit (fresh or processed), where did they obtain their plant material, what fruit traits were important to them, how would they define "good" and "bad" levels of those traits, whether certain trait levels were associated with or more important for different markets, what tree traits were important, what influenced their decision to adopt a new cultivar, and what were the barriers to adopt new cultivars.

Audience survey. From the responses to the producers' pre-survey interviews, a condensed list of nine fruit/tree traits was developed for both fresh and processed peach producers. The list of traits also included "other" making a total of 10 fruit/tree traits to be used as answer options in the formal survey. Traits assessed for fresh peach producers included fruit traits (size, shape, skin color, flavor, firmness, sweetness/soluble solids) and tree traits (disease resistance, productivity, production consistency). "Other" traits for fresh peaches included shelf life, shipping ability, and aroma. Traits assessed for processed peach producers included fruit traits (size, flesh color, flavor, texture, firmness, absence of split pits) and tree traits (disease resistance, productivity, uniform harvest maturity). "Other" traits for processed peaches included ease of flesh separation from stone and sugar level.

We conducted the audience surveys to fresh peach growers at the Mid-Atlantic Fruit and Vegetable meeting, PA (33 producers) and the Southeast Regional Fruit and Vegetable Conference, GA (30 producers). Processed peach growers were surveyed at the California Stone Fruit meeting (26 producers). Producers from neighboring states of where the meetings were held (Georgia and Pennsylvania) attended so the sample for fresh peach producers represented the growers in the southeastern peach region (Alabama, Georgia, South Carolina, North Carolina) and the mid-Atlantic states (New Jersey, Pennsylvania, Maryland, Virginia). We conducted the audience survey at different locations to understand any potential geographical differences in peach producers' preferences for traits. However, we were not able to conduct the audience survey with California fresh peach producers, the state where most fresh peaches are grown. A total of 89 producers participated in the peach surveys, but five responses were incomplete and dropped for the analysis (three from Pennsylvania for fresh peach and two from California for processed peach). A total of 84 responses was used in the audience survey analyses (24 processed and 60 fresh).

A standard audience survey protocol was followed at each site. A RosBREED project scientist introduced the study and explained the overall project's focus to increase the efficiency of new cultivar development by using MAB. In the introductory materials, the scientist explained the potential benefits of the study, provided updates on current breeding endeavors, and explained the 10 fruit/tree traits assessed in the audience survey. The introductory materials were designed to familiarize the participants with the study. A different RosBREED scientist presented at each location.

TurningPoint $^{\mathrm{TM}}$ (Youngstown, $\mathrm{OH}$ ) polling software was used to collect audience responses. The software enables each respondent to submit one answer per question. Each respondent submitted responses using a ResponseCard ${ }^{\mathrm{TM}}$ keypad, hereafter termed "clicker." Additionally, respondents were given a note card to list any other trait not provided on the list of response options. On completion of each question, the software provides instant feedback by graphically displaying results for that question. Such audience polling systems have been shown to engage audiences in a group setting (Hall et al., 2005). Additionally, the polling system expedites surveying larger groups, removes data entry errors, improves ease of use, and reduces time when compared with paper formats (Powe et al., 2009). McCarter and Caza (2009) highlighted the methodological reliability of an audience polling system.

Respondents were asked two introductory questions to familiarize them with polling system mechanics. The first peach trait question inquired about the MOST important fruit or tree trait. Once responses to the first question were completed, the next slide presented the audience with a second question regarding the SECOND MOST important fruit quality or tree trait for a successful peach cultivar. Both questions had the same list of traits. For fresh peaches, the traits were fruit size, fruit shape, fruit skin color, fruit flavor, fruit firmness, fruit sweetness/soluble solids, tree disease resistance, tree productivity, tree production consistency, and "other" traits. For processed peaches, the traits were fruit size, flesh color, fruit flavor, fruit texture, fruit firmness, absence of split pits, disease resistance, productivity, uniform harvest maturity, and "other" traits. The next two slides used the same list of traits but asked participants for their LEAST important and then the SECOND least important trait. The remainder of the survey consisted of questions addressing total acres of peach orchards owned/managed, years involved in the decision-making process of the orchard, 2010 gross farm income, and role in the orchard.

Participants were not asked to rank all 10 fruit/tree traits. Instead, they were asked to indicate the most important, second most important, least important, and second least important trait from the list presented. This method was used to avoid participant fatigue, to engage the audience, and to stay within the time limits of the meetings.

Econometric model. An ordered probit model was used to analyze producers' preferences and rankings for fruit/tree traits. The ordered probit model was used because survey participants' responses were discrete and ordinal. Fresh and processed peach traits were analyzed using separate models. For both fresh and processed peach, there were five levels of importance for the 10 traits in the ordered probit model and each was assigned a value of 1 to 5 . Based on the survey questions responses, a new variable was generated. The most important trait was assigned the value "5," second most important " 4 ," second least important " 2 ," least important " 1 ," and the traits that were not selected for any of these categories were considered a middle choice and assigned the value " 3 ." This method has been successfully used to identify the level of importance of traits for various products (Davis and Gillespie, 2004; Greene and Hensher, 2008).

The producer's ranking of the traits depends on an underlying utility/satisfaction derived from the different traits. Essentially, the respondent knows his or her utility/ satisfaction; however, the researcher does not. As a result, the traits are ranked according to which would provide the respondent with the most benefits (utility). In this instance, the benefits (utility) include all of the elements producers contemplate when ranking 
the fruit/tree traits based on their preferences. Lancaster (1966) theorized that utility is not derived from the product itself but instead from the product's traits. Suppose $U_{i j}$ is the utility/satisfaction that producer $i$ derives from peach trait $j$ and $U_{i j}$ can be expressed as follows for fresh peach producers:

$$
\begin{aligned}
U_{i j}= & \alpha_{0}+\alpha_{1} \text { Size }_{i}+\alpha_{2} \text { Shape }_{i}+\alpha_{3} \text { Color }_{i} \\
& +\alpha_{4} \text { Flavor }_{i}+\alpha_{5} \text { Firmness }_{i} \\
& +\alpha_{6} \text { Sweet }_{i}+\alpha_{7} \text { Productivity }_{i} \\
& +\alpha_{8} \text { Consistency }_{i}+\alpha_{9} \text { Disease }_{i} \\
& +\alpha_{10} \text { Other }_{i}+\beta_{1} \text { Region }_{i} \times \text { Color }_{i} \\
& +\beta_{2} \text { Region }_{i} \times \text { Flavor }_{i} \\
& +\varepsilon_{i j} ; i=1, \ldots, 60(n)
\end{aligned}
$$

Similarly, for processed peach producers the utility/satisfaction can be expressed as follows:

$$
\begin{aligned}
U_{i j}= & \mu_{0}+\mu_{1} \text { Size }_{i}+\mu_{2} \text { Color }_{i}+\mu_{3} \text { Flavor }_{i} \\
& +\mu_{4} \text { Texture }_{i}+\mu_{5} \text { Firmness }_{i} \\
& +\mu_{6} \text { Nopits }_{i}+\mu_{7} \text { Productivity }_{i} \\
& +\mu_{8} \text { Harvestmaturity }_{i}+\mu_{9} \text { Disease }_{i} \\
& +\mu_{10} \text { Other }_{i}+\gamma_{1} \text { Texture }_{i} \times \text { Income }_{j} \\
& +\gamma_{2} \text { Nopits }_{i} \times \text { Acres }_{i}+\gamma_{3} \text { Productivity }_{i} \\
& \times \text { Acres }_{i}+\gamma_{4} \text { Productivity }_{i} \times \text { Years }_{i} \\
& +\gamma_{5} \text { Harvestmaturity }_{i} \times \text { Years }_{i} \\
& +\varepsilon_{i j} ; i=1, \ldots, 24(n)
\end{aligned}
$$

In Eqs. (1) and (2), $\alpha_{j}$ and $\mu_{j}$ are the coefficients associated with the fruit/tree traits; $\beta_{j}$ and $\gamma_{\mathrm{j}}$ are the coefficients associated with the interaction effects between peach traits and peach producers' sociodemographics [e.g., 2010 gross income, years of experience in the decision-making process of peach orchards (hereafter "years of experience"), role in orchard], and the region where the audience survey took place. $\varepsilon_{i j}$ is the residual error term that is not captured by the explanatory variables, which is assumed to follow a normal distribution with mean zero and SD $\sigma_{\varepsilon}$. There are 60 fresh peach producers and 24 processed peach producers, respectively, and 10 fruit/tree traits. Disease resistance was used as the base variable for comparison purposes for both the fresh and processed peach producer results. To investigate the impact of the sociodemographic variables, we generated interaction terms where the trait variables were multiplied with the sociodemographic variables (income, acres, and years of experience). The interaction terms were standardized with mean zero and SD of 1 . Only the significant interaction effects are represented in the models and subsequent tables. Because these estimated models show the importance of a trait relative to disease resistance, we conducted pairwise $t$ tests between the fruit and tree trait coefficients to statistically test for the difference in importance among all quality traits included in the study. The models were estimated using a STATA ${ }^{\mathrm{TM}}$ software package (STATA Corp., College Station, TX).

We estimated the marginal effects to predict the probability that the traits would be ranked in the different levels of importance (most important, second most important, neutral, second least important, least important).
Disease resistance was used as the base variable for comparison purposes. The marginal effects of the interaction terms were also calculated; however, only those that are significant are presented and discussed.

\section{Results}

Summary statistics for participants of the audience surveys are presented in Table 1 . Approximately $33 \%$ of participating fresh peach producers managed orchards that are less than 14 acres and $12.7 \%$ of them managed orchards that are larger than 1000 acres. More than half of the fresh peach producers had more than 20 years of decision-making experience. Approximately $33 \%$ of the fresh peach producers had less than $\$ 50$ thousand 2010 gross farm income and $\approx 31 \%$ of them had more than \$1 million 2010 gross farm income. More than half of the processed peach producers managed 100 to 249 acres of orchards and $\approx 77 \%$ of them had more than 20 years of decision-making experience.

\begin{tabular}{|c|c|c|c|}
\hline Variable & Description & $\begin{array}{c}\text { Fresh peaches }(\mathrm{n}=60) \\
\text { Percentage }\end{array}$ & $\begin{array}{c}\text { Processed peaches }(\mathrm{n}=24) \\
\text { Percentage }\end{array}$ \\
\hline Years & $\begin{array}{l}\text { Participant's years of decision-making experience } \\
\quad 1-5 \\
6-10 \\
11-15 \\
16-20 \\
>20\end{array}$ & $\begin{array}{r}16.13 \\
11.29 \\
8.06 \\
11.29 \\
53.23\end{array}$ & $\begin{array}{c}0 \\
0 \\
15.79 \\
10.53 \\
73.68\end{array}$ \\
\hline Role & $\begin{array}{l}\text { Role of participant } \\
1=\text { Owner } \\
2=\text { Lessee } \\
3=\text { Manager }\end{array}$ & $\begin{array}{r}76.27 \\
1.69 \\
22.03\end{array}$ & $\begin{array}{r}94 \\
6\end{array}$ \\
\hline Region & Location of orchards & $\begin{array}{l}\text { Mid-Atlantic } 52 \\
\text { Southeastern } 48 \%\end{array}$ & California 100 \\
\hline
\end{tabular}
Approximately $33 \%$ of the processed peach producers had $\$ 0.5$ million to $\$ 1$ million 2010 gross farm income and $28 \%$ of them had $\$ 1$ million to $\$ 2.5$ million 2010 gross farm income. Fifty-two percent of the fresh peach orchards were located in the mid-Atlantic states with the remainder in the southeastern region, whereas $100 \%$ of the processed peach producers' orchards were in California.

Fresh peach producers. The ordered probit results of fresh peach producer trait preferences indicate higher importance of fruit flavor when compared with disease resistance followed by

Table 1. Summary statistics for producer demographic variables used in the ordered probit model for fresh and processed peach producers at three peach producer meetings in 2011-12 $(\mathrm{n}=84)$. 
Table 2. Estimated ordered probit model coefficients indicating the relative importance of fresh peach fruit quality and plant traits to fresh peach producers based on audience survey data collected at two peach producer meetings in 2011-12 $(\mathrm{n}=60)$.

\begin{tabular}{|c|c|c|}
\hline Variable & Coefficient $^{\mathrm{z}}$ & SE \\
\hline Fruit size & $0.91 * * *$ & 0.21 \\
\hline Fruit shape & $-1.89 * * *$ & 0.22 \\
\hline Fruit skin color & $-0.79 * * *$ & 0.25 \\
\hline Fruit flavor & $1.49 * * *$ & 0.26 \\
\hline Fruit firmness & -0.13 & 0.21 \\
\hline Sweetness/soluble solids & -0.24 & 0.21 \\
\hline Productivity & -0.01 & 0.22 \\
\hline Production consistency & -0.10 & 0.21 \\
\hline Disease resistance & Base & \\
\hline Otherv & -0.14 & 0.22 \\
\hline Southeast $\times$ fruit skin color $^{\mathrm{y}, \mathrm{x}}$ & $0.17 * * *$ & 0.06 \\
\hline Southeast $\times$ fruit flavor ${ }^{x}$ & $-0.26 * * *$ & 0.07 \\
\hline Cutoff value $1^{\mathrm{w}}$ & -1.75 & 0.17 \\
\hline Cutoff value $2^{\text {w }}$ & -1.22 & 0.16 \\
\hline Cutoff value $3^{\mathrm{w}}$ & 0.98 & 0.16 \\
\hline Cutoff value $4^{w}$ & 1.53 & 0.17 \\
\hline Log likelihood & -589.91 & \\
\hline Pseudo $\mathrm{R}^{2}$ & 0.17 & \\
\hline \multicolumn{3}{|c|}{$\begin{array}{l}\mathrm{z*}, * *, * * * \text { Significant at } P \leq 0.10,0.05 \text {, or } 0.01 \text {, } \\
\text { respectively. }\end{array}$} \\
\hline \multirow{2}{*}{\multicolumn{3}{|c|}{$\begin{array}{l}{ }^{\mathrm{y}} \text { Only significant sociodemographic and } \\
\text { interaction terms are presented. } \\
{ }^{\mathrm{x}} \text { Interaction between fruit trait and the location of } \\
\text { the respondent. }\end{array}$}} \\
\hline & & \\
\hline \multicolumn{3}{|c|}{ "Cutoff value for the ordered probit model. } \\
\hline v"Other" includes shelf life, & nipping ability & \\
\hline
\end{tabular}

fruit size (Table 2). For fresh peach producers, fruit skin color and fruit shape were less important when compared with disease resistance. The importance of fruit firmness, sweetness/soluble solids, productivity, production consistency, and other traits was not significantly different from disease resistance. Southeastern producers placed more importance on fruit skin color than mid-Atlantic producers. Additionally, fruit flavor was less important for southeastern producers than for mid-Atlantic producers.

The marginal effects results for fresh peach traits indicated that fruit flavor and fruit size had a greater probability of being selected as the most important trait when compared with disease resistance. Fruit shape and fruit skin color had a lower probability of being selected as the most important trait when compared with disease resistance. Fruit firmness, sweetness/ soluble solids, productivity, production consistency, and other traits were not significantly different in importance from disease resistance.

The marginal effects also indicated the impact of the location of peach orchards on the probability of trait selection (Table 3 ). Southeastern producers had a greater probability than mid-Atlantic producers of selecting fruit skin color as the most important trait. Conversely, mid-Atlantic producers had a greater probability than southeastern producers of selecting fruit flavor as the most important trait (Tables 3 and 4).

Results from the pairwise $t$ tests indicate that fruit flavor and fruit size were ranked significantly more important than the other fruit/tree traits (Table 5). Fruit shape and fruit skin color were ranked significantly less important than the other fruit/tree traits. Fruit firmness, sweetness/soluble solids, productivity, production consistency, and other were not significantly different from each other.

Processed peach producers. The ordered probit results indicate processed peach producers placed higher importance on fruit size followed by absence of split pits and fruit firmness when compared with disease resistance (Table 6). The estimated marginal effects of the relative importance of processed peach traits to producers are reported in Table 7. Fruit flavor was considered less important than disease resistance. Fruit color, fruit texture, tree productivity, uniform harvest maturity, and other traits were not significantly different in importance than disease resistance.

Only the significant interaction terms are listed in Table 6 . The importance of fruit texture became greater as producers' 2010 gross incomes increased. Additionally, producers with greater years of experience valued tree productivity and uniform harvest maturity more than did their experienced counterparts.

Table 3. Estimated marginal effects of relative importance of fresh peach traits to fresh peach producers based on audience survey data collected at two fresh peach producer meetings in 2011-12 $(\mathrm{n}=60)$.

\begin{tabular}{|c|c|c|c|c|c|}
\hline & $\begin{array}{l}\text { Least important trait } \\
(\text { ranking }=1)\end{array}$ & $\begin{array}{l}\text { Second least important trait } \\
(\text { ranking }=2)\end{array}$ & $\begin{array}{l}\text { Not selected } \\
(\text { ranking }=3)\end{array}$ & $\begin{array}{l}\text { Second most important } \\
\text { trait (ranking }=4 \text { ) }\end{array}$ & $\begin{array}{l}\text { Most important trait } \\
\quad(\text { ranking }=5)\end{array}$ \\
\hline & $\mathrm{dy} / \mathrm{dx}^{\mathrm{z}}$ & $\mathrm{dy} / \mathrm{dx}^{\mathrm{z}}$ & $\mathrm{dy} / \mathrm{dx}^{\mathrm{z}}$ & $\mathrm{dy} / \mathrm{dx}^{\mathrm{z}}$ & $\mathrm{dy} / \mathrm{dx}^{\mathrm{z}}$ \\
\hline Predicted probabilities & 0.05 & 0.08 & 0.73 & 0.09 & 0.05 \\
\hline Fruit size & $-0.05 * * *$ & $-0.07 * * *$ & $-0.16 * *$ & $0.11 * * *$ & $0.17 * * *$ \\
\hline Fruit shape & $0.49 * * *$ & $0.14 * * *$ & $-0.44 * * *$ & $-0.11 * * *$ & $-0.08 * * *$ \\
\hline Fruit skin color & $0.13 * *$ & $0.09 * * *$ & -0.10 & $-0.07 * * *$ & $-0.05 * * *$ \\
\hline Fruit flavor & $-0.06 * * *$ & $-0.09 * * *$ & $-0.34 * * *$ & $0.14 * * *$ & $0.35 * * *$ \\
\hline Fruit firmness & 0.01 & 0.01 & -0.00 & -0.01 & -0.01 \\
\hline Sweetness/soluble solids & 0.03 & 0.03 & -0.01 & -0.03 & -0.02 \\
\hline Productivity & 0.00 & 0.00 & 0.00 & -0.00 & -0.00 \\
\hline Production consistency & 0.01 & 0.01 & -0.00 & -0.01 & -0.01 \\
\hline Disease resistance & Base & Base & Base & Base & Base \\
\hline Other & 0.02 & 0.02 & -0.00 & -0.02 & -0.01 \\
\hline Southeast $\times$ fruit skin color $^{y}$ & $-0.02 * * *$ & $-0.02 * * *$ & -0.00 & $0.02 * * *$ & $0.02 * * *$ \\
\hline Southeast $\times$ fruit flavor ${ }^{y}$ & $0.03 * * *$ & $0.03 * * *$ & 0.00 & $-0.03 * * *$ & $-0.03 * * *$ \\
\hline
\end{tabular}

z*, **, ***Significant at $P \leq 0.10,0.05$, or 0.01 , respectively.

${ }^{\mathrm{y}}$ Interaction between fruit trait and the location of the respondent.

Table 4. Estimated marginal effects of relative importance of fresh peach traits (by region) to fresh peach producers based on audience survey data collected at two fresh peach producer meetings in $2011-12(\mathrm{n}=60)$.

\begin{tabular}{|c|c|c|c|c|c|}
\hline & $\begin{array}{l}\text { Least important trait } \\
\quad(\text { ranking }=1)\end{array}$ & $\begin{array}{c}\text { Second least } \\
\text { important trait } \\
(\text { ranking }=2 \text { ) }\end{array}$ & $\begin{array}{l}\text { Not selected } \\
(\text { ranking }=3)\end{array}$ & $\begin{array}{l}\text { Second most important } \\
\text { trait }(\text { ranking }=4)\end{array}$ & $\begin{array}{l}\text { Most important trait } \\
\quad(\text { ranking }=5)\end{array}$ \\
\hline & $\mathrm{dy} / \mathrm{dx}^{\mathrm{z}}$ & $\mathrm{dy} / \mathrm{dx}^{\mathrm{z}}$ & $\mathrm{dy} / \mathrm{dx}^{\mathrm{z}}$ & $\mathrm{dy} / \mathrm{dx}^{\mathrm{z}}$ & $\mathrm{dy} / \mathrm{dx}^{\mathrm{z}}$ \\
\hline Fruit flavor & $-0.03 * * *$ & $-0.06 * * *$ & -0.34 & $0.11 * * *$ & $-0.05 * * *$ \\
\hline \multicolumn{6}{|l|}{ Mid-Atlantic } \\
\hline Fruit skin color & $0.13 * *$ & $0.09 * * *$ & -0.10 & $-0.07 * * *$ & $-0.05 * * *$ \\
\hline
\end{tabular}

z*, $* *, * * *$ Significant at $P \leq 0.10,0.05$, or 0.01 , respectively. 
Table 5. Pairwise $t$ test comparisons of the importance of selected fresh peach fruit quality and plant traits based on audience survey data collected at two fresh peach producer meetings in $2011-12(\mathrm{n}=60)$.

\begin{tabular}{|c|c|c|c|c|c|c|c|c|c|}
\hline & Fruit size & Fruit shape & $\begin{array}{l}\text { Fruit skin } \\
\text { color }\end{array}$ & Fruit flavor & $\begin{array}{c}\text { Fruit } \\
\text { firmness }\end{array}$ & $\begin{array}{c}\text { Sweetness/ } \\
\text { soluble solids }\end{array}$ & Productivity & $\begin{array}{l}\text { Production } \\
\text { consistency }\end{array}$ & Other \\
\hline Fruit size & - & - & - & - & - & - & - & - & - \\
\hline Fruit shape & $2.81 * * * z$ & - & - & - & - & - & - & - & - \\
\hline Fruit skin color & $1.71 * * *$ & $-1.10 * * *$ & - & - & - & - & - & - & - \\
\hline Fruit flavor & $-0.58 * *$ & $-3.38 * * *$ & $-2.28 * * *$ & - & - & - & - & - & - \\
\hline Fruit firmness & $1.04 * * *$ & $-1.76^{* * *}$ & $-0.67 * * *$ & $1.62 * * *$ & - & - & - & - & - \\
\hline Sweetness/soluble solids & $1.16^{* * *}$ & $-1.65 * * *$ & $-0.55 * *$ & $1.74 * * *$ & 0.12 & - & - & - & - \\
\hline Productivity & $0.92 * * *$ & $-1.88 * * *$ & $-0.78 * * *$ & $1.50 * * *$ & -0.12 & -0.23 & - & - & - \\
\hline Production consistency & $1.02 * * *$ & $-1.79 * * *$ & $-0.69 * * *$ & $1.60 * * *$ & -0.02 & -0.14 & 0.09 & - & - \\
\hline Other & $1.06 * * *$ & $-1.75 * * *$ & $-0.65 * *$ & $1.63 * * *$ & 0.01 & -0.10 & 0.13 & 0.04 & - \\
\hline
\end{tabular}

z*,**,***Significant at $P \leq 0.10,0.05$, or 0.01 , respectively.

Table 6. Estimated ordered probit model coefficients indicating the relative importance of processed peach fruit quality and plant traits to processed peach producers based on audience survey data collected at two peach producer meetings in $2011-12(\mathrm{n}=24)$.

\begin{tabular}{|c|c|c|}
\hline Variable & Coefficient $^{z}$ & $\overline{\mathrm{SE}}$ \\
\hline Fruit size & $1.96^{* * *}$ & 0.52 \\
\hline Fruit color & -0.37 & 0.46 \\
\hline Fruit flavor & $-1.53 * * *$ & 0.45 \\
\hline Fruit texture & -0.92 & 0.60 \\
\hline Fruit firmness & $1.66 * * *$ & 0.52 \\
\hline Absence of split pits & $1.85 * *$ & 0.80 \\
\hline Productivity & -0.80 & 1.39 \\
\hline Uniform harvest maturity & -2.23 & 1.62 \\
\hline Disease resistance & Base & \\
\hline Other $^{\mathrm{v}}$ & 0.60 & 0.52 \\
\hline Fruit texture $\times$ income $e^{y, x}$ & $0.30 *$ & 0.16 \\
\hline Absence of split pits $\times$ acres $^{x}$ & $-0.43 * *$ & 0.20 \\
\hline Productivity $\times$ acres $^{\mathrm{x}}$ & $-0.43 * *$ & 0.20 \\
\hline Productivity $\times$ years experience ${ }^{\mathrm{x}}$ & $1.22 * * *$ & 0.41 \\
\hline Uniform harvest maturity $\times$ years experience ${ }^{x}$ & $1.09 * *$ & 0.49 \\
\hline Cutoff value $1^{\mathrm{w}}$ & -2.11 & 0.44 \\
\hline Cutoff value $2^{\mathrm{w}}$ & -1.48 & 0.42 \\
\hline Cutoff value $3^{\mathrm{w}}$ & 1.52 & 0.44 \\
\hline Cutoff value $4^{\mathrm{w}}$ & 2.25 & 0.46 \\
\hline Log likelihood & -133.01 & \\
\hline Pseudo $\mathrm{R}^{2}$ & 0.26 & \\
\hline
\end{tabular}

z*,**,***Significant at $P \leq 0.10,0.05$, or 0.01 , respectively.

y Only significant sociodemographic and interaction terms are presented.

${ }^{\mathrm{x}}$ Interaction between fruit trait and the sociodemographics (2010 income, acres, years experience) of the respondent. The acreage used in the estimation is the midpoint of each acreage category. The years of experience used in the estimation is the midpoint of each years of experience category. The income used in the estimation is the midpoint of each years of experience category.

${ }^{\mathrm{w}}$ Cutoff value for the ordered probit model.

v"Other" include ease flesh separation from stone and sugar level.

As the producers' acreage increased, the absence of split pits and productivity became less important.

Results from the pairwise $t$ test indicate that fruit size, absence of split pits, and fruit firmness were the most important traits but were not significantly different in importance from each other (Table 8). Absence of split pits was not significantly different from other fruit traits. Other traits were more important than fruit color and fruit flavor. Fruit skin color was more important to processed peach producers than fruit flavor.

\section{Discussion and Conclusion}

To improve producers' likelihood of adoption of and consumers' demand for the new cultivar, breeders should have knowledge of the relative importance that these stakeholders place on fruit/tree traits before breeding a new cultivar. Understanding the needs of industry stakeholders before developing a cultivar decreases the risk of developing a new cultivar. This study estimates the relative importance of peach fruit and tree traits to both fresh and processed peach producers based on audience surveys at three peach producer association meetings. An ordered probit model was used to analyze producers' responses. Although some of our results are consonant with findings from previous consumer studies, others are not. Fruit flavor and fruit size were the most important fruit quality traits identified by eastern U.S. fresh peach producers, in agreement with previous studies. For example, previous studies found fruit flavor impacts consumer preferences (Crisosto et al., 2003; Park and Florkowski, 2003; Predieri et al., 2005), whereas fruit size impacts the price the producer obtains for peach (Jordan et al., 1986; Parker et al., 1991). We found fruit color and firmness were not as important as fruit size and flavor to producers, in contrast to a previous study showing fruit color and firmness are important to consumers (Wolf et al., 2003). Overall, our results suggest that fresh peach producers make cultivar decisions partially based on their perception of consumers' demands. Peach breeders need to take producers' preferences into consideration and synthesize the information on consumers' and producers' preferences for traits in developing new peach cultivars. Differences in the importance of traits between southeastern and mid-Atlantic peach producers could be the result of having distinctly different climate stresses, cultivar availability, and market settings. We found southeastern producers consider fruit skin color to be relatively more important and fruit flavor to be less important than do mid-Atlantic producers. Therefore, peach breeders who target the southeastern region should place more importance on fruit skin color and less importance on flavor compared with breeders who target the mid-Atlantic region in breeding new cultivars.

Processed peach growers, like fresh peach growers, placed emphasis on fruit size. Processed peach growers also indicated absence of split pits and fruit firmness were important traits. Split pits are highly undesirable in a processed peach, because this causes internal defects, grading problems, and increased likelihood of rot problems that can quickly spread to other non-affected peach (Taylor, 2013). Fruit firmness is important to processed peach producers because it helps fruit retain their shape through handling and processing. Income, size of the orchard (in acres), and years experience also impacted the relative importance of processed peach traits. Processed peach breeders should also emphasize productivity, which was especially recognized by producers with more years of experience and producers with smaller orchard sizes, and uniform harvest maturity, which was also ranked highly by producers with more years of experience.

A key objective of RosBREED is to obtain and use information on the importance of peach fruit and tree traits from all supply chain groups and share this information with peach breeding programs to increase the likelihood of new peach cultivar success. This study, including both fresh and processed peach products, provides critical information to increase the efficiency of peach cultivar development. Its results can be used to guide future industry growth 
Table 7. Estimated marginal effects of relative importance of processed peach traits to processed peach producers based on audience survey data collected at one peach producer meeting in $2011-12(\mathrm{n}=24)$.

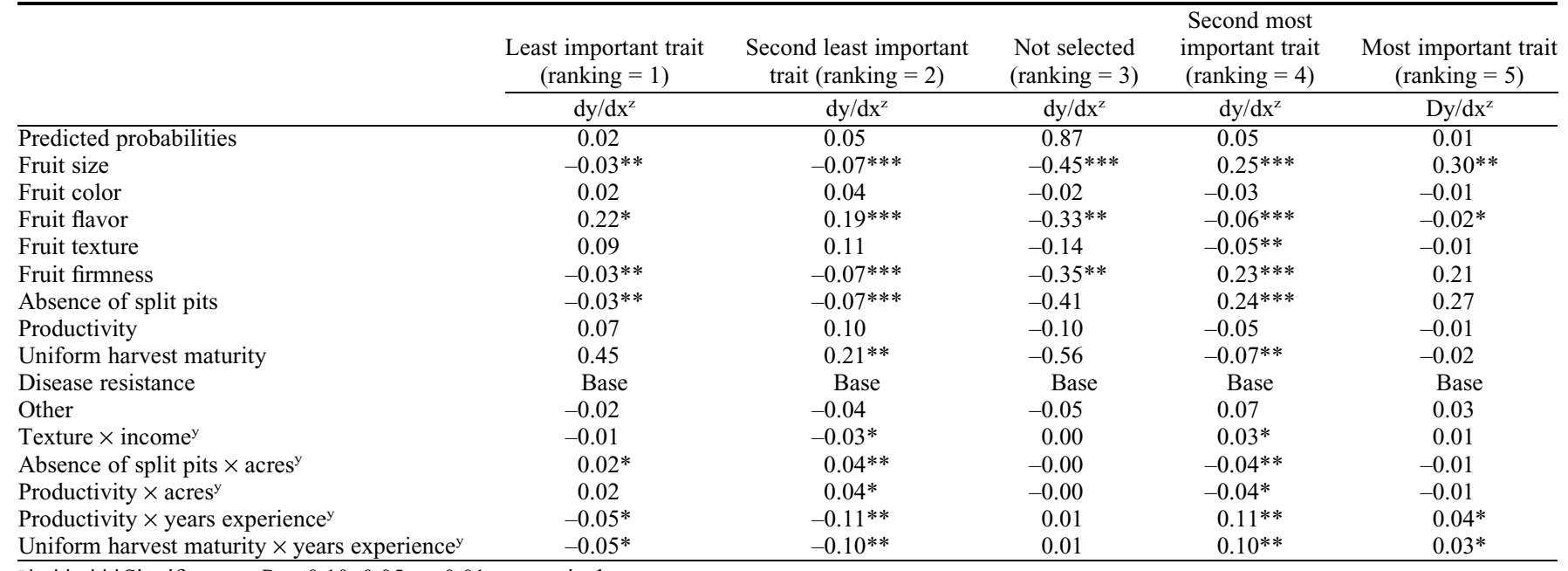

z*,**,***Significant at $P \leq 0.10,0.05$, or 0.01 , respectively.

'Interaction between fruit trait and the sociodemographics (2010 income, acres, years experience) of the respondent. The acreage used in the estimation is the midpoint of each acreage category. The years of experience used in the estimation is the midpoint of each years of experience category. The income used in the estimation is the midpoint of each years of experience category.

Table 8. Pairwise $t$ test comparisons of the importance of selected processed peach fruit quality and plant traits based on audience survey data collected at one processed peach producer meeting in 2011-12 $(\mathrm{n}=24)$.

\begin{tabular}{|c|c|c|c|c|c|c|c|c|c|}
\hline & $\begin{array}{l}\text { Fruit } \\
\text { size }\end{array}$ & $\begin{array}{l}\text { Fruit } \\
\text { color }\end{array}$ & $\begin{array}{l}\text { Fruit } \\
\text { flavor }\end{array}$ & $\begin{array}{c}\text { Fruit } \\
\text { texture }\end{array}$ & $\begin{array}{c}\text { Fruit } \\
\text { firmness }\end{array}$ & $\begin{array}{c}\text { Absence of } \\
\text { split pits }\end{array}$ & Productivity & $\begin{array}{l}\text { Uniform harvest } \\
\text { maturity }\end{array}$ & Other \\
\hline Fruit size & - & - & - & - & - & - & - & - & - \\
\hline Fruit color & $2.32 * * * z$ & - & - & 一 & - & - & - & 一 & - \\
\hline Fruit flavor & $3.49 * * *$ & $1.16^{* * *}$ & - & - & - & 一 & 一 & 一 & - \\
\hline Fruit texture & $2.88 * * *$ & 0.56 & -0.61 & - & - & 一 & - & - & - \\
\hline Fruit firmness & 0.30 & $-2.02 * * *$ & $-3.19 * * *$ & $-2.58 * * *$ & - & - & - & - & - \\
\hline Absence of split pits & 0.11 & $-2.21 * * *$ & $3.38 * * *$ & $-2.77 * * *$ & -0.19 & - & 一 & 一 & - \\
\hline Productivity & $2.76^{* *}$ & 0.44 & -0.73 & 0.12 & $2.46^{*}$ & $2.65^{*}$ & - & - & - \\
\hline Uniform harvest maturity & $4.19 * *$ & 1.87 & 0.70 & 1.31 & $3.89 * *$ & $4.08 * *$ & 1.43 & 一 & - \\
\hline Other & $1.35 * * *$ & $-0.97 *$ & $-2.13 * * *$ & $-1.53 * *$ & $1.05 * *$ & 1.24 & -1.41 & $-2.84 *$ & - \\
\hline
\end{tabular}

z*,**,***Significant at $P \leq 0.10,0.05$, or 0.01 , respectively.

through the synchronization of supply chain member needs.

\section{Literature Cited}

Alpuerto, V.E., G.W. Norton, J. Alwang, and A.M. Ismail. 2009. Economic impact analysis of marker-assisted breeding for tolerance to salinity and phosphorous deficiency in rice. Rev. Agr. Econ. 31:779-792.

Bruhn, C.M. 1995. Consumer and retailer satisfaction with the quality and size of California peaches and nectarines. J. Food Qual. 18:241-256.

Brunke, H. and M. Chang. 2012. Peach profile. Agr. Marketing Resource Center. 2 Aug. 2013. <http:// www.agmrc.org/commodities_products/fruits/ peach-profile/>.

Crisosto, C.H., G. Crisosto, and E. Bowerman. 2003. Understanding consumer acceptance of peach, nectarine and plum cultivars. Intl. Conf. on Quality in Chains. An Integrated View on Fruit and Vegetable Quality 604:115-119.

Davis, C.G. and J.M. Gillespie. 2004. What role does specialization play in farm size in the U.S. Hog Industry? Southern Agr. Econ. Assoc. Annu. Mtg., Tulsa, OK.

Dirlewanger, E., E. Graziano, T. Joobeur, F. GarrigaCaldere, P. Cosson, W. Howad, and P. Arus. 2004. Comparative mapping and marker-assisted selection in Rosaceae fruit crops. Proc. Natl. Acad. Sci. USA 101:9891-9896.

ERS USDA. 2013. Fruit and tree nut yearbook spreadsheet files (89022). 2 Aug. 2013.
$<$ http://usda.mannlib.cornell.edu/MannUsda/ viewStaticPage.do?url=http://usda01.library. cornell.edu/usda/ers/./89022/2011/index.html .

Evans, K., J. Luby, S. Brown, M. Clark, Y. Guan, B. Orcheski, C. Schmitz, C. Peace, E. van de Weg, and A. Iezzoni. 2012. Large-scale standardized phenotyping of apple in RosBREED. ISHS postharvest unlimited. Acta Hort. 945:233-238.

Florkowski, W.J., T.A. Park, and A. Bilgic. 2003. External and internal quality index in fresh peach marketing. Acta Hort. 604:219-224.

Greene, W.H. and D.A. Hensher. 2008. Modeling ordered choices: A primer and recent developments. New York University. 29 Mar. 2013. $<$ http://w4.stern.nyu.edu/emplibrary/greene $\%$ 20OrderedChoiceModeling\%5B1\%5D.pdf $>$.

Hall, R.H., H.L. Collier, M.L. Thomas, and M.G. Hilgers. 2005. A student response system for increasing engagement, motivation, and learning in high enrollment lectures. Proc. of the Eleventh Americas Conf. on Information Systems. p. 1-7. Iezzoni, A., C. Weebadde, J. Luby, C. Yue, C.P. Peace, N. Bassil, and J. McFerson. 2010. RosBREED: Enabling marker-assisted breeding in Rosaceae. Acta Hort. 859:389-394.

Jordan, J.L., R.L. Shewfelt, and S.E. Prussia. 1986. The value of peach quality characteristics in the postharvest system. IX Symp. on Hort. Econ. XXII IHC 203:175-182.

Lancaster, K.J. 1966. A new approach to consumer behavior theory. J. Polit. Econ. 74:132-157.

Luby, J. and D. Shaw. 2001. Does markerassisted selection make dollars and sense in a fruit breeding program? HortScience 36:872-879.

McCarter, M.W. and A. Caza. 2009. Audience response systems as a data collection method in organizational research. J. Mgt. Organ. 15:122-131.

NASS. 2013. National statistics for peaches. 2 Aug. 2013. <http://www.nass.usda.gov/Statistics_by_ Subject/result.php?E8E36177-ED51-34EAB 8C3-8B8BA6E82453\&sector $=$ CROPS\& group $=$ FRUIT $\% 20 \% 26 \% 20$ TREE $\% 20$ NUTS \& comm $=$ PEACHES $>$.

Park, T. A. and W.J. Florkowski. 2003. Selection of peach varieties and the role of quality traits. J. of Agr. and Resource Econ. 28:138-151.

Parker, D., D. Zilberman, and K. Moulton. 1991. How quality relates to price in California fresh peaches. Calif. Agr. 45:14-16.

Powe, B.D., R.C. Faulkenberry, L. Harmond, and D.L. Cooper. 2009. Evaluating the use of an audience response technology system to collect research data among African American elders. Ageing Intl. 34:60-66.

Predieri, S., P. Ragazzini, and R. Rondelli. 2005. Sensory evaluation and peach fruit quality. In VI Intl. Peach Symp. 713:429-434.

Taylor, K.C. 2013. Splitting in peaches. University of Georgia. 7 Aug. 2013. <http://www.ent. uga.edu/peach/peachhbk/harvest/splitpit.pdf>.

Wolf, M.M., A.J. Martin, and T. Cagianut. 2003. An analysis of the importance of ripeness to consumers in the United States when making a purchase decision for peaches, plums, and nectarines. Acta Hort. 604:61-67. 